\title{
13
}

\section{People and policy in the development and destruction of Yagga Yagga outstation, Western Australia}

Scott Cane

I have called this contribution 'people and policy in the development and destruction of Yagga Yagga outstation' because it seems to me that the relationship between people was more significant than that between policy and people in the social experience of residents at Yagga Yagga. Yagga Yagga was an outstation of Balgo Mission in the Great Sandy Desert of Western Australia (see Map 13.1). My exposure to the story of Yagga Yagga situates the primacy of the community's experience in an amorphous middle ground, across the interstice of policy development and policy delivery that begs exemplification if the successes and failures of Yagga Yagga are to be understood and learnt from. The consideration here is less about the nature of policy and its consequences for people and more about the interdependent relationship between government policy, its agents of administration and the people who are affected by that policy and its administrators. 
EXPERIMENTS IN SELF-DETERMINATION

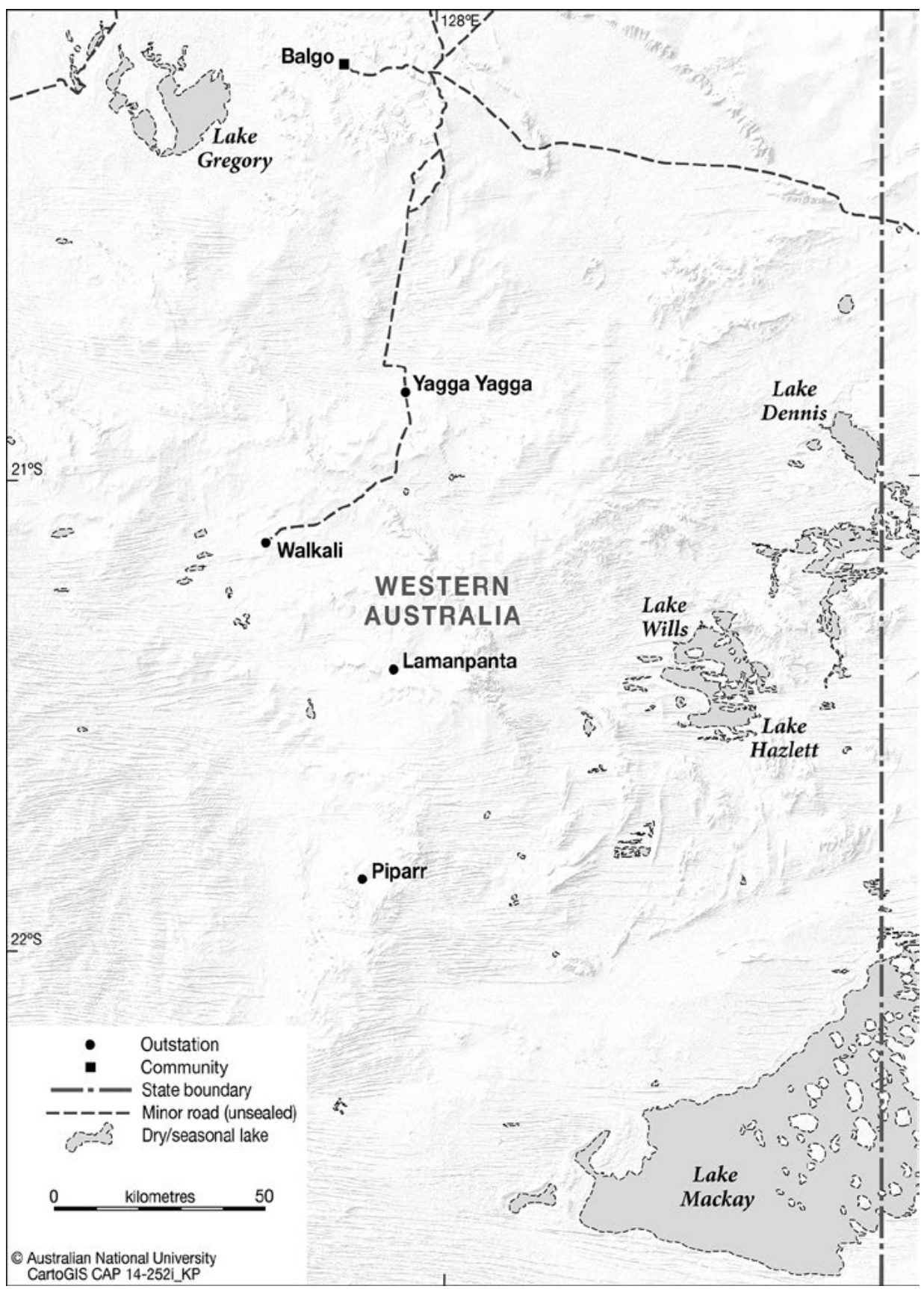

Map 13.1 Yagga Yagga outstation.

Source: Karina Pelling, CartoGIS, ANU College of Asia and the Pacific 
Policy is, as a social and political goal, an expression of human experience- a formulation by one group of people in recognition and response to the needs of another. Policy is therefore necessarily subjective, formulated and implemented as an intersubjective action that necessitates, in significant part, a serial expression of interpretation and assessment: discretion hinged on proportional measures of comprehension, capacity, responsibility and accountability in a bureaucratic world of differentiated possibilities filtered through the personality, opinion, energies and commitment of the people constituting the agencies dispensing it. The administration of policy necessarily situates people, and so the discretion of those people is an important articulating force of social change.

The experience of people at Yagga Yagga raises a number of questions in this regard. What, for example, were the processes that played out in the development and delivery of policy for Yagga Yagga? What factors influenced the implementation of policy, why was the policy needed and how was the policy solution managed on its return journey from the community to the Government? How were the social needs of the people received, understood and transformed into effective policy delivery and how was that delivery transformed into social benefit concordant with the original need? How did the relationship between the needs of the people and the directives of policy translate across the amorphous area of bureaucracy positioned between them? What was the social consequence of the nature of translation?

It is my experience of Yagga Yagga that the people in the administrative process had great influence in the development and destruction of the community; and perhaps this 'agency effect' also has great consequence across Aboriginal affairs generally. People and the agencies they inhabit have, I suspect, an unrecognised (and easily overlooked) centrality in the effective and ineffective delivery of Aboriginal policy.

There is, I believe, an unaccountable space here as Aboriginal policy is essentially rights-based policy, articulated and administered broadly within the covenant of self-determination. This means that the policy configuration must be loose, in so far as 'loose' equates with and allows for the social and geographic flexibility necessary for free and unfettered political expression. Free and unfettered expression translates into variable (and at times idiosyncratic) form and directive that implicitly lack definition and contingent regulation and accountability - the allowable consequence of which is that policy delivery is articulated between the policymakers and the policy-takers in a manner that is itself self-determined. Everyone in the chain of delivery has a qualified 'voice' such that no voice resonates particularly and no voice is particularly authoritative, responsible or accountable. The intersubjectivity of the multiple voices of self-determination - between the desert and the desk-necessitates 
(and must result in) indeterminate consequences for the people in need of the policies developed for them. There is, in other words, a space between policy and people across which policy generally, and homelands policy particularly, succeeds or fails as a consequence of the discretionary powers conditioned by self-determination and configured by the political perceptions, sympathies, aspirations and abilities of its administrators.

Success or failure is itself a matter of perception, but the notion of unfettered discretion as a consequential hallmark of self-determination suggests that the aspirations of people and the intentions of policymakers may be lost in translation; policy intentions and people's aspirations may be subverted in favour of the intentions and aspirations of the individuals and agencies situated in relation to them. The inevitable conclusion is that 'discretion' becomes a central and significant component in the delivery of successful policy outcomes and the positive realisation of community well-being. The history of Yagga Yagga indicates that, regardless of the policy approach or the aspirations of the community, outcomes were largely determined by the middlemen and women operating in relation to them, without particular accountability to either.

\section{The voice of self-determination}

I want to start the chapter in 1979 because in that year one hears the emerging voice of self-determination from the northern margins of the Great Sandy Desert. It is heard in the original sense of the policy, as a political voice regarding 'future development' and 'control of policy and decision making' (Snowdon 1990) - not the later, conflated agenda of self-management, administration and 'responsibility', with its attendant notions of 'freedom' as eventually articulated by the Fraser Government (Fraser and Simons 2010: 390).

In 1979, the call from north-western Australia was for self-determination aloneas a political voice. This was the era of Noonkanbah (Hawke and Gallagher 1989) and saw the birth of the Kimberley Land Council (KLC). It was also the first public record of an intelligent and charismatic young Balgo spokesman, Mark Moora, on the newly formed KLC executive (KLC 1979: 2). Mark would become the voice of Yagga Yagga.

In that year, he wrote to the director of the WA Aboriginal Lands Trust, 'seeking rights to his communities traditional lands'. ${ }^{1}$ Those lands had been mapped by Ronald Berndt in 1972 and lay south of Balgo, extending as far south as Lake Mackay, with Yagga Yagga near their northern margin.

1 Letter to Director of Aboriginal Lands Trust, 20 January 1979. Hevern 1979: 18. 
By 1980, people were travelling widely through their homelands on the back of heritage surveys associated with oil exploration (Akerman 1980, 1981, 1982; Palmer 1980; Cane and Novak 1980, 1981), driven largely by the policy commitments of the Liberal State Government and the duty of the minister under Section 10 of the Aboriginal Heritage Act (AH Act), and the proximal vision of the Noonkanbah conflict. Regional oil exploration necessitated large-scale archaeological and anthropological surveys and saw the arrival of Kim Akerman, Kingsley Palmer, Peter Bindon and myself on the scene. The combined fieldwork capacity of these individuals, knowledge of senior men and exploration requirements placed people back in their country for the following years and led to the discovery of potable water in the sand plains on the northern margin of that exploration area. This was very close to the country of Mark's father and the birthplace of his sister, Nellie Njamme.

By 1980, the larger homeland movement across the desert had been under way for some time - and, as an articulation of self-determination, people were determining a preference to leave the violent communities established for them outside their country and return to a quiet, simple, autonomous life in small camps in country. The homeland movement here was a movement born more from the desires of people than the direction of policy, although the Federal Government had created a political platform, a place and a possibility (through its policy of self-determination, land rights legislation and grants of $\$ 10,000$ from the Council for Aboriginal Affairs) (Cane 1989).

The homeland movement was, at that time, a movement ahead of Federal and State policy preparedness: Federal administration was struggling to keep up with the momentum and character of the movement that, as I recall, was seen as an event of some social, economic and political concern. It was an unmanaged movement of colossal geographic scale: there were five desert homeland settlements in 1975, 41 by 1980 and 72 by 1984. By the late 1980s, there were more than 100 outstations across the desert, accounting for more than 3,000 people. More widely in remote Australia, there were 165 homelands in 1981 and a population of 4,200 people, 400 to 600 homelands in 1986 with a population in the order of 10,000 people and growing to about 1,000 outstations housing between 13,000 and 32,000 people across Australia by the late 1990s (Myers 1976; Penny et al. 1977; Stead 1982; Nathan and Japanangka 1983; Cane and Stanley 1985: 32; Blanchard 1987; Altman et al. 1998). 


\section{Balgo Hills community}

In the early 1980s, Balgo Hills Mission, a Catholic mission established in 1939, was a large and sophisticated enterprise. It was an artificial community incorporating a mission, cattle station, service station, store, service centre, fuel agency, bank, post office and air charter service, as a multi-million dollar jigsaw of religious fundamentalism, community management, government accountability, financial management, unprofitable business enterprises, community upkeep and welfare, technical maintenance and servicing, education and health in an isolated, demanding environment, occupied by about 300 naive and traditional desert nomads facing rapid social change who had been trained, in part, to fix fences, make beds and serve food in the community kitchen. ${ }^{2}$

At the same time, regional governmental perspectives regarding selfdetermination shifted into a policy of self-management and 'self-government' and in the case of Balgo, sought the transfer of community responsibility to the local people, unmindful of their notable lack of capacity to carry it. None of the Aboriginal people I knew wanted to take over the management of Balgo, although regional bureaucrats were enthusiastic on their behalf. Desert people were not equipped to deal with the necessary management and decision-making to ensure the continued smooth operation of Balgo. Self-management was effectively thrust on them.

At the regional level the mission was being starved out of operation: in 1982, government funding allocation was reduced to $\$ 3,900$ per quarter, or $\$ 37$ a day. ${ }^{3}$ Not surprisingly, social problems that did not exist began to appear: community confusion in 1982 became a community crisis in 1984 and, after the dismissal of Father Ray Hevern, Balgo became a community in chaos. ${ }^{4}$ Balgo Hills was formally incorporated as an Aboriginal Association in 1984 and that same year saw riots, communal drunkenness, the sexual assault of a female employee, violent intimidation, vandalism and theft, assault at knife-point and breakins: an 'almost schizophrenic change' towards anger, petulance and violence, unprecedented in the 'missionary years'.

\footnotetext{
2 Brief to the Minister dated 19 August 1983, from B. W. Easton, Acting Director, Department of Aboriginal Affairs [hereinafter DAA], Western Australia. For ethnographic background on the Balgo community, see Poirier (2005); McCoy (2008).

3 Letter to Minister of Aboriginal Affairs from Father R. Hevern, 27 December 1982.

4 Letter from P. Sheridan, 8 November 1983, to Senior Assistant Director Community Development Branch, of Aboriginal Affairs, WA; Report on Visit to Balgo Mick Marshall 17/2/1987, File Note DAA19/1984 Department, Cane 1989.

5 Community records 1984: handwritten, S. Cane 1989.
} 
Non-Aboriginal people began running grog into the community; there were 11 drunken assaults on white staff between 1985 and 1987, by which time the handful of missionaries had been replaced with 40-50 white staff. By 1987, conditions at Balgo were described as 'appalling', but in a speedy repositioning of history, this disaster was now seen as the community's fault by the Department of Aboriginal Affairs (DAA). The Community Council was described as 'having lost direction, credibility and the ability to manage' (as if they had once had it). The problems facing them were recognised, somewhat belatedly, as being 'beyond their control'. ${ }^{6}$

It is not surprising therefore that some within the community sought an alternative solution that was in their control, involving fewer people, fewer problems, and among family in home country. People began moving south to the water point established by Mobil Oil and acquired by Mark Moora in 1984 .

Meanwhile, back at Balgo, office workers had fled the community, children had vandalised a charter plane, thefts continued and brawling was common (Guild 1988). There were two large riots between police and Balgo residents at Halls Creek, both of which were stopped by senior men who travelled up from Yagga Yagga for that purpose. When I was asked by the Community Council to visit Balgo in 1989 and reflect on its future, I was formally advised by the regional office of the DAA that the Government could not guarantee my safety.

\section{Yagga Yagga}

\section{0s: Peace and tranquillity}

Yagga Yagga was established as a homeland in 1985 largely independent of government funding, with the assistance of the Institute for Appropriate Technology in Alice Springs. It was a local movement inspired by regional developments among the Pintupi to the south (see Myers 1986; and this volume) and driven by local people - in opposition to and in contrast with Federal and State Government policy initiatives at the time. ${ }^{7}$

6 Telex 30 December 1982 from DAA Perth to Balgo; File note DAA5/2/85 and 18 February 1985; Marshall 1987; Anon. 1989, Confidential report: 42-443; DAA file note 31 December 1987; Phelan To Community Health Derby, 21 October 1987; DAA confidential paper, ‘Balgo-New Management Plan', 9 April 1987; also File Note 16 April 1987 from Cedric Wyatt, Telex to DAA 2 July 1984; Cane (1989).

7 Undated Council minutes and DAA file note 26/2/86, DAA file note 16/3/1987, Cane 1989. 
The name Yagga Yagga is taken from the Wati Kutjarra ('Two Men') Tjukurrpa (Dreaming) and means 'to be quiet' (in the context of the Two Men walking quietly across the plains to avoid waking a large sleeping snake). The name was applied to the small settlement and was indicative of the circumstances that gave rise to it: a place of intended peace and tranquillity.

Yagga Yagga was not, in this sense, a product of nostalgic desire for a return to the past, ${ }^{8}$ nor a confused attempt to mix the past with the present or amalgamate traditions with modernity. It was a local solution to the terrible social problems at Balgo Hills, created, in the final instance, by policy directives engendered and driven by the regional office of the DAA. Yagga Yagga emerged as an escape from the consequences of poor government policy configured by the intentional manipulation of the emergent policy of self-determination redressed as an opportunity for Aboriginal self-management, which was, at root, a poorly disguised excuse for removing the missionaries. Yagga Yagga was less a return to the past than a solution to the present.

In 1986, Yagga Yagga consisted of four galvanised-iron sheds with verandahs and a series of corrugated-iron shelters and was occupied by about 60 Ngarti, Kukatja, Warlpiri and Pintupi-speaking people. In the same year, Mark Moora acquired $\$ 68,000$ for refrigeration units, an airstrip upgrade, a bulldozer, a second-hand four-wheel-drive and fuel. Discussions were taking place for a part-time school. There was also a chook pen and a communal tap and bath fed by a header tank filled each morning with a diesel pump. ${ }^{9}$

The first 'Desert Women's' project began with the involvement of Sonja Peters. Balgo painting had started; the majority of painters painted and lived at Yagga Yagga, in country. An account of their experiences was published (Tjama et al. 1997).

In the late 1980s, Yagga Yagga was officially recognised as 'a refuge for those who wanted to escape the drunkenness and unrest at Balgo' (Anon. 1989: 40). It was well-managed and strategically placed in terms of traditional country and resources. The community model was copied from Nyirrpi, with part-time schooling, fortnightly store runs and health visits from Balgo.

The new settlement and associated community aspirations required some additional infrastructure, and I drafted and costed a proposal for a four-year, $\$ 4.5$ million homelands program in 1989. The program was intended to provide infrastructure (and associated opportunity) proportional to the needs and

\footnotetext{
8 But broadly in line with homelands motivation as summarised in Coombs et al. (1983: 220).

9 Balgo Community council allocated $\$ 68,000$ for these items in $1986-87$. Undated Council Minutes and DAA File Note, 26 February 1986.
} 
capacity of its intended occupants: basic houses, airstrips, roads, solar-powered radios and refrigeration, water bores with hand pumps, tractors for local use, and unregistered vehicles for use on the lands (Cane 1989; Cane and Stanley 1990).

The Federal Government was by then supportive of the homeland movement and, after the House of Representatives, Return to Country report (Blanchard 1987), had allocated some $\$ 50$ million in support of the larger movement. Minister Gerry Hand made a special, discretionary grant of \$4.5 million for the Yagga Yagga program. ${ }^{10}$

In contrast, the State Labor Government had conducted its own 'Task Force Investigations' into Balgo's problems and expressed 'serious' but unspecified 'concerns' about the homelands program and proposed instead the establishment of a police station at Balgo. ${ }^{11}$ In 1990, community violence and vandalism at Balgo almost ceased. The police station was not yet built.

The Aboriginal and Torres Strait Islander Commission (ATSIC) replaced the DAA in 1990. ATSIC was not prepared to carry on DAA's funding commitment to Yagga Yagga, and I was asked by the regional office of DAA to commit the remaining allocation - more than $\$ 3.7$ million - in the remaining 17 weeks of the 1989 financial year (between April and July 1990).

The homelands program was thus established rather more quickly than planned, with Yagga Yagga completed, along with smaller outstations at Walkali, Lamanpanta and Piparr, within a radius of $80 \mathrm{~km}$. The program saw an almost immediate resettlement of the area that lasted for several years - about the duration that recurrent funding was provided to maintain communication across the larger area.

As funding evaporated (and vehicles broke down), people fell back to Yagga Yagga, which then housed about 150 permanent residents. ${ }^{12}$ Yagga Yagga was described as a magnificent success - notably, as a community relying on minimal non-Aboriginal personnel. There were just two white people (Chris Carey first, followed by Robert Taylor) employed sequentially across that period, with cyclical visits of nursing and teaching staff.

10 I discussed the Yagga Yagga program with the minister at Oak Valley in South Australia during negotiations for the establishment of an ATSIC regional council. The grant was made in 1989.

11 Letter to DAA from Aboriginal Areas Protection Authority (hereinafter AAPA), 19 April 1989; and see Anon. (1989), addressed in detail in Cane and Stanley (1990).

12 Current list of names and addresses at Yagga Yagga as at 30 June 1997, List of names, Kimberley Public Health Unit, 10 April 1997. The numbers swelled to about 500 people during one period of initiation ceremonies in the early 1990s. 
With exceptions in each case, there was no drinking at the outstations and no vandalism. Traditional landowners asserted authority in the context of their gender, family and seniority without the assistance of white people or police. Vehicles were relatively well maintained, with people paying for the repairs from their own savings. ${ }^{13}$ The local tractors were used as intended for local foraging and wood collection. One of those tractors was still operating as intended in 2008 - 18 years after delivery. People regularly travelled the $8-15 \mathrm{~km}$ to adjacent waterholes and sweet potato fields for recreation and food. ${ }^{14}$

ATSIC's initial engagement with Yagga Yagga was, however, problematic, as it stumbled with staffing and management problems in its first years. Part of the new management regime presented the desert people with a cycle of relatively inexperienced Anglo-Aboriginal middle-class administrators who had their own views of what was good and acceptable for desert people and, as Aboriginal people themselves, no longer saw the need for advice from non-Aboriginal specialists like myself.

When I went to meet new ATSIC staff in Kununurra in 1991, no one knew anything about the homeland developments at Yagga Yagga; no one had been there or read reports written relating to the movement, and there were no copies in the office. Policy programming and implementation were difficult for other reasons as well. In the early 1990s, for example, ATSIC's administrative structure was divided into three program areas, 19 subprograms with 47 components and 109 subcomponents and 115 sub-subcomponents (ATSIC 1992), and in the two areas in which I was principally involved, serviced from Kalgoorlie and Kununurra, there were eight different regional managers and 13 different project managers in the first two years.

By 1992, however, ATSIC had a National Homelands Policy and Yagga Yagga met its funding criteria: it had land tenure, occupancy, potable water and servicing (O'Donoghue 1992: 5) and began to reap material benefits. Recurrent and capital funding increased from just more than $\$ 50,000$ in 1992 to more than $\$ 750,000$ in 1993. Yagga Yagga was given new architecturally designed three and fourbedroom homes with flushing toilets, a huge new store, a new clinic, a new multi-roomed office, larger fuel storage, community lighting, electricity in every home and a massive generator to run them.

13 Notable exceptions are recorded in Cane and Stanley (1990).

14 The resources in this area are described in detail in Cane (1989). 
The material growth brought bigger budgets and more complicated machines and systems that necessitated increased specialised support. Yagga Yagga crept happily beyond its own management capacity ${ }^{15}$ and successfully grew into a small Balgo-but was a more distant community and thus more difficult to service.

Yagga Yagga thus became materially rich but logistically poor. In 1996, for example, it had a recurrent budget of more than $\$ 1.3$ million but 'only had a nurse visiting the community on $61 / 2$ days' over a six-month period. ${ }^{16}$ In 1997 there was only one visit by the nurse each fortnight, the road was 'bad' and the 'telephone service' was 'intermittent' ${ }^{17}$ There were 126 adults receiving wages at Yagga Yagga in that year, ${ }^{18}$ suggesting a population of more than 200 people. Decisions were still made by the Traditional Owners of the land, the community was described as 'cohesive' and enjoyed the benefit of 'good community staff'. ${ }^{19}$ Funding peaked in 1998 at more than \$2 million dollars that financial year.

This period coincided with a change in State Government from Labor (Premier Carmen Lawrence) to Liberal (Premier Richard Court), and the Ministry of Aboriginal Affairs came under the direction of five different ministers between 1990 and $1997 .{ }^{20}$ They pursued an alternative policy of communal consolidation and control in the context of modernisation with an emphasis on law and order, with dubious success, as implied by the drunken riots by Balgo residents at Halls Creek in 1996 that saw the siege of the police station for more than five hours and led to 66 arrests.

The State's policy solution was to strengthen the police presence, add night patrols, create Aboriginal wardens, provide vocational training and employment, improve access to sport and recreation, and teach various short courses for which the State Government allocated \$1.76 million that financial year; 20 students at Balgo were enrolled in short courses in literacy, numeracy, arts and crafts. ${ }^{21}$

At that time, Yagga Yagga was busy, fully occupied and healthy. Trees had grown and there were no litter or vandalism. Something of its vitality can be seen in a kind of Yagga Yagga scrapbook prepared by Tjama and others (1997) between 1987 and 1995. Balgo, in comparison, had just seen the fatal stabbing

\footnotetext{
15 Details of these budgets were recorded by myself from files held (and copied) at Yagga Yagga in 2002.

16 Letter from Community to Tommy Stevens MLC, 26 March 1997.

17 Letter from Yagga Yagga, 3 February 1997.

18 Yagga Yagga wages sheet (signed), 6 June 1997.

19 Conversation with the then regional manager for ATSIC, at Kununurra (Cane Diary 2002: 145).

20 These being: Carmen Lawrence (1990); Judith Watson (1991); Kevin Mison (1993); Kevin Prince (1994); Kim Hames (1997).

21 August 1996: Legislative Council questions on notice, 30 October 1996 and 5 November 1996; Blagg and Valuri (2003).
} 
of a girl and the severe beating and spearing of the accused, whose fingerprints, unfortunately, were not on the knife. The police had been stationed at Balgo for two years by this time. ${ }^{22}$

\section{0s: The stress of success}

The success of Yagga Yagga in its first decade of occupation attracted the interest, engagement, opinion and influence of various agencies and individuals. Intentions were generally good, but, as I recall them, the outcomes were bad, usually unintended.

The sense of purpose, for example, generated by the successful settlement at Yagga Yagga created interest in other land-related matters, and in 1993 the community was keen to have their residential status in country matched by recognition of their traditional rights and interests in their homelands. Mark Moora organised a meeting to that effect. The meeting was attended by the KLC, which, in company with their lawyer, subverted the community's aspirations and drafted a letter instructing the KLC, its lawyer and anthropologists 'to act on the community's behalf in relation to mining on the land and the defense of the Mabo title for the lands'. The community was told that 'everyone ... must sign the letter before they go. The people filed up to sign and the meeting closed'. ${ }^{23}$ Nothing happened, and despite repeated requests by the community for engagement and assistance, ${ }^{24}$ Yagga Yagga would wait 13 hard years before its native title was recognised - then through the efforts of others. ${ }^{25}$ By that time, Yagga Yagga had been destroyed.

The late 1980s and early 1990s were also a period of 'fertility and creativity' and 'flowering of expression' among Balgo artists, who were in fact living at Yagga Yagga (Watson 2003: also footnote 30, p. 366). This was a problem for Yagga Yagga, as the art centre, art coordinators and buying public were in Balgo. Initially, the painters travelled backwards and forwards. But people complained and asked for the industry to be based at Yagga Yagga where the painters lived and the country they painted was located ${ }^{26}$ The non-Aboriginal people associated with the industry, however, were not interested in living at Yagga Yagga and the new artistic direction was away from their country. The establishment of 'Warlayirti Artists' - named, revealingly, after the Kingfisher Dreaming of the Balgo area,

\footnotetext{
22 Cane Diary 13-18, 1995.

23 Confidential: Minutes from Yagga Yagga Meeting, 13-14 May 1993.

24 Letter from Mark Gregory, Kimberley Regional Land and Heritage Unit, ALRS WA, 1 March 1996, and again on 25 June 1996.

25 Payi Payi on behalf of the Nguurrpa People v the State of Western Australia (2007 FCA 2113 [October 2007]); Cane (2006).

26 DAA Field Notes 123/6/87, point 5, 'Painting — Old people should paint at Yagga Yagga and not return to Balgo anytime sister calls'.
} 
and not a Dreaming from the country to which the painters belonged ${ }^{27}$ - and the establishment of a multi-million dollar art complex at Balgo sucked people from Yagga Yagga (Cowan 1994, 1999; Watson 2003; De Ishtar 2005).

The art business also created a more immediate social problem: senior painters earned upwards of $\$ 300,000$ per year, with resultant direct and indirect community disengagement, family conflict, suicide, alcoholism, substance abuse and jail terms. The eventual establishment of a Women's Law and Culture Centre, as a kind of gender-restricted outstation for ageing women near the water tank at Balgo, furthered competition for Yagga Yagga's human resources (De Ishtar 2000).

Both attractions created a demographic tension that destabilised Yagga Yagga, and ultimately the Balgo-based agencies effectively extracted the majority of grandparents then living with family at Yagga Yagga, seemingly unaware of the importance of that generation in desert society.

Another strain on Yagga Yagga's viability in the 1990s emerged from the unconsidered and unintended impacts of royalty payments from goldmining in the adjacent Northern Territory. Gold discovery and mining took place in the Granites region of the Tanami Desert between 1987 and 2000, driven largely by the significant discovery of the 3-million-ounce Callie gold deposit in 1992one of the great modern gold discoveries, and leading to some 260 exploration licences granted and pending, and 53 agreements between the Central Land Council (CLC) and different companies across the area by 2000. Royalty payments were described as considerable in 1997 and amounting to millions of dollars to Aboriginal communities and individuals (Manning 1997, quoted in Ellias 2007; Manning 2002; also Altman and Levitus 1999; ABA 2006; Scambary 2013). No beneficiaries lived at Yagga Yagga, but all those with country on the eastern side of the homelands were related to people who were.

The consequence was that approximately one-quarter of Yagga Yagga's population regularly left the community to join cashed-up relations: the community destabilised, families fragmented and fought over access to vehicles, money and alcohol, which in turn led to inter-family feuds and fuelled community conflict and a more permanent drift away from Yagga Yagga.

As the 1990s drew to a close, these emerging problems were aggravated by the poor selection of white staff, including one who had a violent relationship with the residents, abusing them regularly and ultimately threatening them with a loaded gun. Residents left Yagga Yagga in droves at this time. The regional manager at the time told me 'we drove them away'.

27 And incorrectly attributed to Pai Pai Napangarti from Yagga Yagga in Nichols and Williams (2006). 
During that same period, Mark Moora had sought and won election to the ATSIC Regional Council. He, like many other Western Desert men I knew in this process, was seduced by the experience and the meretricious charms of city life, money, girls and alcohol, which accompanied regular Regional Council board meetings. The absence of his consolidating influence on the residents at Yagga Yagga began to tell.

\section{0s: Inconspicuous compassion}

When I visited Yagga Yagga in 2000, the population had declined to about 30-40 people, and included a large proportion of children. ${ }^{28}$ The infrastructure surrounding them was so large and complicated they could not meet its technical and administrative requirements. There was also a distinct breakdown in communication and servicing from Balgo, leading to a decline in health and education, vehicle failure and shortages of food and fuel. Lack of road maintenance made access to Yagga Yagga increasingly difficult after each wet season's rains. The population (and perhaps their emotional stamina) seemed to have dropped below its critical mass: people were increasingly drawn back to Balgo, where everybody else lived.

The regional ATSIC office now took a hard line in response to the community's difficulties. As people left the community and financial requirements went unmet, ATSIC threatened to cut funding for their Community Development Employment Projects (CDEP) and administrative costs. The regional manager told me his office simply sent a fax to Yagga Yagga 'saying CDEP was no more'. ${ }^{29}$

In response, Mark Moora and other community members drove to Kununurra with a view to protest. They entered the ATSIC office (sober) and, after asking the staff to leave, smashed it to pieces with wooden clubs. Mark told me 'they are trying to destroy Yagga Yagga, so I do the same to them'. This was a calculated act of civil disobedience after which Mark and those involved went to the police station to be arrested. The police released them. The regional manager at the time felt Mark was 'trying to get justice. He wanted to be heard' ${ }^{30}$

This period of difficulty and decline coincided with, and was probably aggravated by, a shift in national policy that sought to mainstream services, develop established communities at the expense of outstations and homelands

28 Cane Diary entry, November 2000.

29 Notes from discussion with regional manager at the ATSIC Office in Kununurra, 2001.

30 Cane Diary 2002: 146. 
yet, somewhat inconsistently, was also intended to listen directly to the desires of 'individuals, families and communities' (Collins et al. 2003; and see Sanders 2004). ${ }^{31}$

But the regional arm of ATSIC (soon to be Aboriginal and Torres Strait Islander Services, ATSIS) appeared not to be listening. By 2003, Federal policy was beginning to walk hand-in-hand (Vanstone 2005b) with State policy, so was now inclined to more authoritarian solutions. The regional office ceased to be sympathetic to the ensuing social fragmentation at Yagga Yagga and began a pointed bureaucratic attack regarding compliance with 'Terms and Conditions', appropriate vehicles use, 'breaches of Grant Conditions' and the increasing likelihood of 'withholding funds' and, people felt, closing the community. ${ }^{32}$

The community responded that ATSIS staff visited Balgo but refused to visit Yagga Yagga to discuss the ongoing problems; phone calls were never answered or returned; vehicles were misused after attending ATSIS and Council of Australian Government (COAG) meetings in Halls Creek; computer software required to manage $\mathrm{CDEP}$ was inoperable due to dated software; and, in the absence of a functioning CDEP program, people were leaving to obtain money at Balgo. ${ }^{33}$ The community subsequently approached the CDEP help desk and was advised to send their computer discs to Adelaide. ${ }^{34}$

The correspondence points to a degree of departmental obstinacy that is both consistent and inconsistent with incongruent Federal Government policy at the time. That policy stressed accountability, on one hand, and compassion (with implied understanding and flexibility), on the other: 'Indigenous Australians, as individuals, in their families and communities can only be said to have a real voice when governments actually listen directly to them' (Vanstone 2005b). ${ }^{35}$

\footnotetext{
31 ATSIC's fiscal powers were transferred to a new independent organisation, ATSIS, in 2003, proposed for abolishment in 2004 and abolished in 2005. Vanstone (2005a, 2005b, 2005c); Curtis et al. (2005). Peter Shergold, Department of the Prime Minister and Cabinet Management Advisory Committee, Speech to launch 'Connecting Government: Whole-of-Government Responses to Australia's Priority Challenges', Report No. 4, 20 April 2004, p. 4, quoted in McCausland 2005: 16.

32 Letter from Regional Manager, ATSIC Kununurra, to Chairperson, Yagga Yagga, Re use of CDEP, December 2003; Letter from Field Officer to Yagga Yagga Chairperson, Re 2002/2003 Audit report - initial follow up, 7 October 2003.

33 Letter to Alastair Brown, Regional Manager ATSIS, from Julian Carson, 4 December 2003; Letter from Bernard Njamme to Nita Warren, ATSIS, re CDEP schedule and Computer, 24 November 2003; Letter from Quality Assurance Officer, ATSIS, Kununurra, to The Chairperson, Yagga Yagga, 27 August 2003; Letter from Field Officer to Yagga Yagga Chairperson, Re 2002/2003 Audit report -initial follow up, 7 October 2003, compare Yagga Yagga Aboriginal Corporation Financial Statements for Year ended 30 June 2000, Barry Hansen, Chartered Accountant, Darwin.

34 Three letters faxed to ATSIS from Yagga Yagga, 24 November 2003.

35 Shergold, Speech to launch 'Connecting Government'.
} 
In the case of Yagga Yagga, it would seem the regional office of ATSIS was not listening. It was, instead, overtly hostile to the community's requests for help. The lack of administrative assistance and the active removal of departmental support had a debilitating effect on the community's sense of purpose and state of mind. External problems were exacerbated by internal ones: almost all the old people had gone, teenagers who had grown up at Yagga Yagga and knew no other home were left without role models and saw their families, home and community dissolving.

The desert had become a lonely, pointless place and Yagga Yagga had become an environment of uncertain opportunity and certain boredom. Their world might be inferred from the neon and nightmarish visions the children painted of it on the walls of their empty four-bedroom homes. These are not the images of desert nomads sold by the Balgo Art Centre, but they are the visions of young lives coloured by the neon of TV and violent videos; they are visions of despair, boredom and frustration: clear social commentary for anyone who was willing to look.

The sense of disempowerment was compounded by insecurity, compounded by despair among occupants who, for their own part, knew their community was on the verge of closure yet lacked the skills and experience to do anything about it. The available correspondence in 2003 suggests an intentional effort to close the community by forcing people to leave and receive Centrelink payments elsewhere. ${ }^{36}$

Despair and disillusionment created inter-family and inter-community conflict as residents at Yagga Yagga accused those who had moved back to Balgo of failing to support Yagga Yagga. In counter-accusation, those Balgo families claimed they stopped visiting Yagga Yagga because of the proprietorial anger launched against them by those still living there. Community conflict thus replaced community consensus and this further destabilised the settlement.

Administrative issues receded into the background in the presence of more immediate and pressing social problems. Yagga Yagga residents found themselves increasingly isolated from the broader social environment of Balgo, and the compounding social disorientation led to greater personal despair and a general sense of irrelevance and futility. Bouts of drinking at Halls Creek increased exponentially. The latter consequence further aggravated the attitude of DAA officials, who felt, with some justification, that the residents at Yagga Yagga should spend more time in their homelands and less time in Halls Creek.

36 Letter from Bernard Njamme to Nita Warren; Letter from Quality Assurance Officer, ATSIS; Letter from Field Officer to Yagga Yagga Chairperson, Re 2002/2003 Audit report. 
Matters were made worse as Mark Moora began to suffer extreme anxiety and depression: he was, quite literally, being driven mad. His mental state was aggravated by the development of cataracts and increasing blindness, by the manslaughter of his daughter-in-law, and his wife's cancer and subsequent death. Mark believed his wife had been 'sung' and he told me he had 'spirits in his head' after she died. He was so disturbed he went to the Balgo cemetery one night, where he was found by his family trying to retrieve her body and bring her back to life.

Mark continued to live at Yagga Yagga and speak at meetings, pursuing his aspirations for native title commandeered by the KLC some 13 years previously. But he was a shadow of himself, under heavy medication and otherwise catatonic - and spent most of the day sitting alone in front of the Yagga store staring into space.

Eventually just one family remained permanently at Yagga Yagga - along with five male teenage petrol-sniffers taken there under care. The sniffers were exposed to frequent drinking, homosexual behaviour and explicit heterosexual pornography. They were taken to Halls Creek by the carer one night, where, perhaps in imitation of the pornography they had been exposed to, they raped a young girl so violently that she subsequently required a colostomy bag. They were tried for the aggravated rape and sent to jail.

That same night a young man, Calwyn, left alone at Yagga Yagga with his grandmother, hanged himself from the swings in the school playground. The young man was buried with sand brought from his grandfather's country at Piparr, where he had lived as a child in the far south of the homelands. The boy's family returned to Yagga Yagga after three months in sorry business and a distressing funeral. They made another trip to the young man's country at Piparr - in the same, now decrepit, vehicle I had provided for them in 1991. They broke down $100 \mathrm{~km}$ south of Yagga Yagga in the heat of early summer and were saved by the boy's uncle, Peter Njamme, who walked alone to Yagga Yagga with a dog that died on the way.

That same week a journalist from the West Australian newspaper arrived in Yagga Yagga. Unaware of recent events, she described Yagga Yagga as a 'picture post card community' under the headline 'Community turns into ghost town' (Paganoni 2003).

In 2004, ATSIS advised Yagga Yagga that its funding would be cut if the family could not 'do the wages bill', the information for which was 'in the computer' that no one could operate. The family rang me, I rang ATSIS, but the field officer was rude, uncomprehending and completely unwilling to do anything to help. 
The next year, ATSIS hired contractors to place a locked gate over the road leading to Yagga Yagga, actively blocking occupation of the settlement and its homelands. In July 2006, Yagga Yagga was advertised for sale: the 'remote community infrastructure, buildings, power plant and mobile equipment' at Yagga Yagga would be auctioned on Friday, 28 July 2006. ${ }^{37}$ That same year, in the absence of any visitation at Piparr, and perhaps to prevent any further visitation, the last nomads living uncontacted in the far south of the homelands burnt the place to the ground.

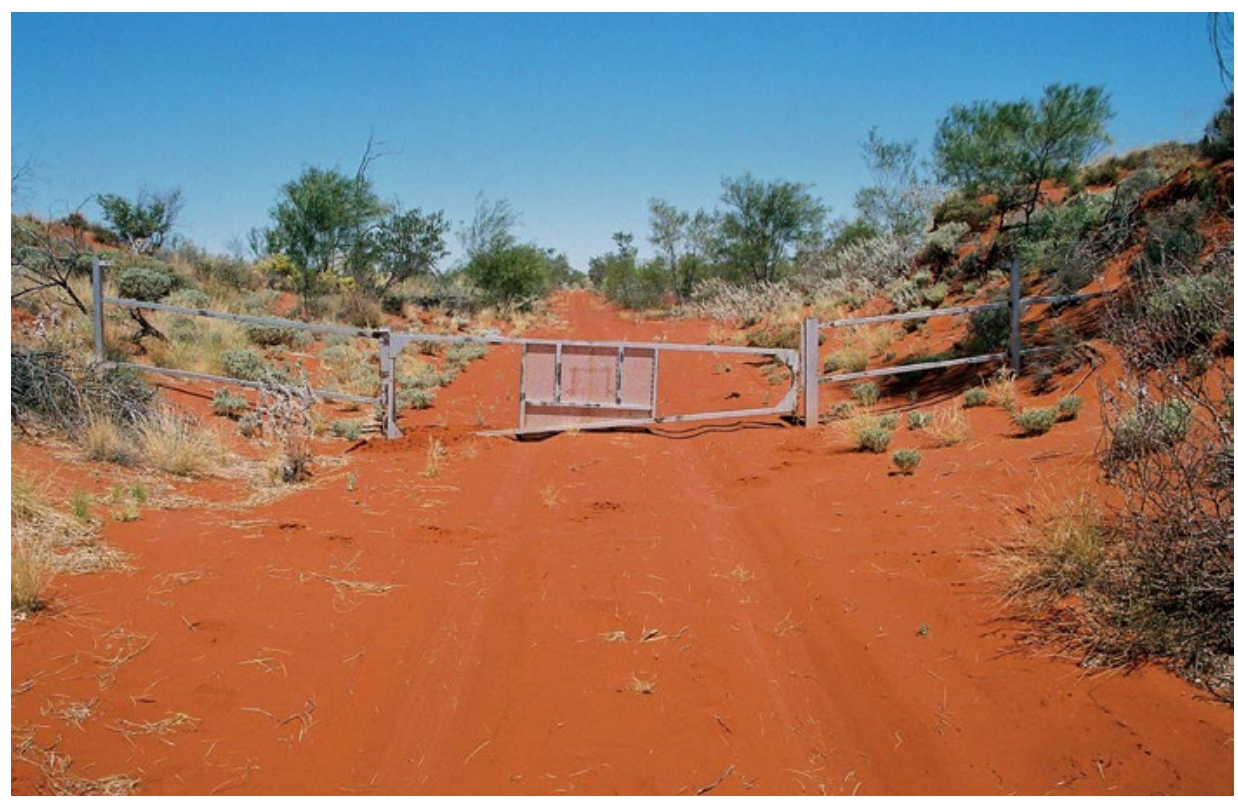

Figure 13.1 The locked gate.

Photo: Scott Cane

And so, after many blows to the body, Yagga Yagga and its homeland movement were destroyed. The last residents were forced to live at Balgo, which continued its nightmare of death, injury, violence, drunkenness, substance abuse, delinquency, vandalism and brawling - despite an enlarged police presence and the establishment in 2005 of 'multi functioning policing facilities' that were apparently 'a holistic approach, designed to provide a total environment for safety and security' (DIA 2005: 166). By 2007, women were calling for even more policing, a greater police presence and female as well as male wardens (Kapululangu 2007). In 2008-09, the suicide rate at Balgo was 100 times higher than anywhere else in Western Australia. ${ }^{38}$

37 Evans and Clarke National Valuers and Auctioneers Australia Wide, [Advertisement], The Advertiser, [Adelaide], 8 July 2006.

38 Hope Coroner's report, 2011. 


\section{Hindsight as foresight}

After a quarter of a century, many broken lives and some $\$ 17$ million in expenditure, everyone is back at Balgo or scattered in various degraded and drunken conditions across the fringe of the Kimberley. Peter Njamme, who walked to save his family after the funeral of his nephew Calwyn, was buried in December 2013, having been found dead on the street in Broome. The grandchildren of the original residents are dead, alcoholic, unhappy, despairing or depressed. Their Facebook posts reveal troubled minds: insomnia ('staying up all night coz I can't sleep. I have sleeping problem. I need to buy sleeping pills'; 'still watching cartoon with my son. And its nearly 3:00 o' clock [am]'); substance abuse, violence and gambling ('I had a dream because people are smoking too much Gunja, fighting, too much jealousy. Gambling too much'); nightmares ('I was on top of the pit looking down as they were falling. I heard them crying out to me in language 'help, help' ... I tried to reach out but their hands split away from my hands'); and salvation ('I love Jesus with all my heart, mind, soul and strength. Nothing can separate me from his love'; 'when you ignoring Jesus it's like you choosing hell. No air, no light, no love, no peace, no joy, no water, no happiness, there is no rest'). They could be describing life at Balgo.

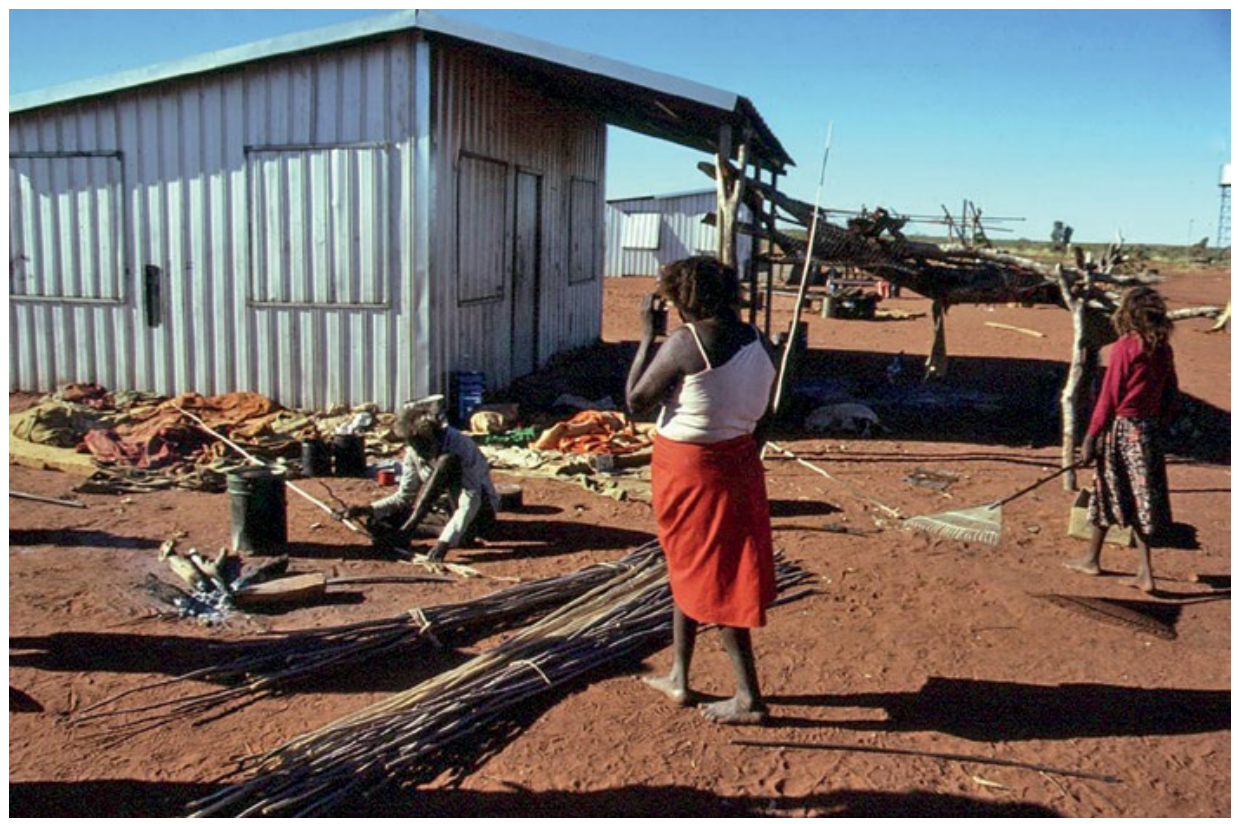

Figure 13.2 Bundles of newly collected spear shafts.

Photo: Scott Cane 
And this unhappy consequence happened despite the desire of the local people and despite the evolution of policy that was designed for better things. In the broader scheme of those things, and despite inconsistencies in Federal and State policy, the homeland movement fell at the local level, through lack of support, overcapitalisation, bad and unsympathetic management, and disparate competing and destabilising influences.

The 'politics of suffering' (see Sutton 2009) was, in this case, an 'administration of suffering' in so far as things might have been significantly better if those situated between the policies and the people had made more informed, discerning and compassionate decisions in relation to the people they were employed to assist; if policies had not simply been reduced to police, and if the aspirations and agendas of intermediaries had been conditioned by expert advise, experience, communal consensus, moderation, compassion, understanding and practicality.

In the case of Yagga Yagga, policy direction and personal aspirations did not dictate or necessitate negative outcomes; these outcomes were largely realised by agents and administrators on the ground. The choices made across Yagga Yagga's history might reasonably have been otherwise. Hindsight is a regrettable historical device, but it does not take a great deal of reflection to imagine things differently and see how life at Yagga Yagga might have been rather betterparticularly as that vision was readily apparent at the time, to almost everyone who took the time to look, listen and think about the orientation of policy formulation and regional decision-making impacting the small community. The future was relatively plain to see.

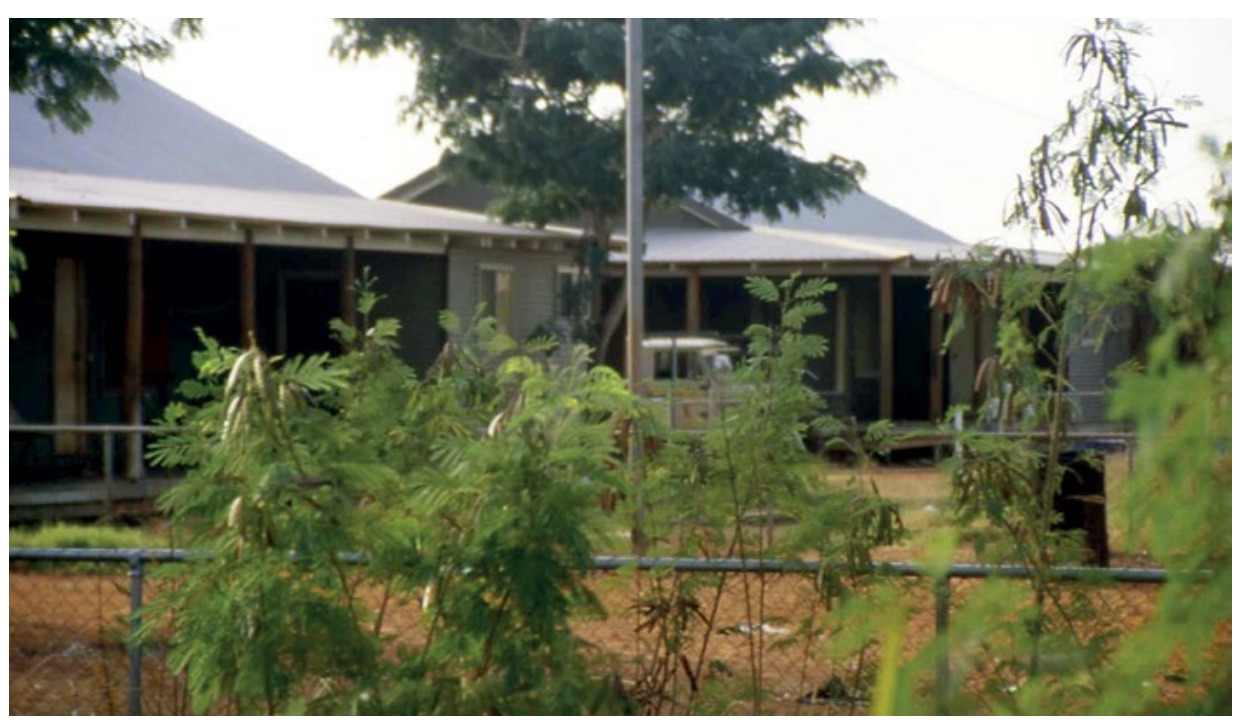

Figure 13.3 Yagga Yagga in 2002.

Photo: Scott Cane 
We might reflect, for example, on how things might be at Balgo had the voice of self-determination not been confused (and manipulated) for a desire for selfmanagement in those early years of transition. And would it have been too much to expect State and Federal governments to develop complementary policy solutions to the emerging problems at Balgo in those transitional years? It is not unreasonable to imagine that everyone may have benefited if local administrators had listened more carefully to community concerns and solutions. And, as some of us recall, there was a time when local lawmen had sufficient authority to manage community conflicts. Might they not have been supported instead of sidelined by an enforced presence of foreign and transient police? And, to the extent that different policy solutions were manifested through different government agencies, might things have been different if the homeland option was allowed to run its programmed course, and not rushed by changes in departmental structure and discordant funding policy? Should I have refused to develop the program in haste and let the remaining $\$ 3.7$ million return to Treasury?

One might also reflect that the communities at both Balgo and Yagga Yagga may have been more stable if royalty payments from the Tanami goldmines had been managed in accordance with conditional parameters of positive communal and personal outcome. And similarly, Yagga Yagga might not have been destabilised if its artists had been encouraged to stay in their homelands and not lured to Balgo. How might the children of Yagga Yagga have prospered if the Balgo art and women's centres were built at Yagga Yagga and had not extracted their grandmothers and grandfathers for resettlement and financial gain in Balgo?

And how much more energised and enriched might Yagga Yagga have been if the KLC had not commandeered the community's native title aspirations in 1993? And what if ATSIC's urban vision for Yagga Yagga had been qualified by the cultural context of the population it was intended for? What if ATSIC had not turned Yagga Yagga into a sophisticated community that required external administration, coordination and support? And, one might ask, if the departmental vision was to develop the outstation in such a manner, might it not have been reasonable to expect its population to be trained accordingly? And, in lieu of appropriate training, might it have seemed reasonable for the regional officers to obsess less about the community's financial and managerial obligations and accountability and more about the means and mechanism to resolve them? Might not someone have recognised that the emergent community conflict, violence and alcoholism needed attention and could be traced back to the social dislocation and distress paralleling it? Perhaps there was another solution to the community's difficulties other than cutting funds, blocking access, closing the community and selling its infrastructure. 
And, in the final event, as State and Federal policy began to accord, authority was regionalised and ministerial presentations ostensibly lent an emotive eye and ear to the needs of people, might not it have been reasonable for regional officers to actually listen to and work with the people they were paid to assist? Is it unrealistic to expect government employees to be properly trained, properly informed, have analytical compassion and be skilled in management directed towards positive social outcomes in the context of the funding made available to them? Might it not be reasonable to ask that government officers and community employees in remote and regional Aboriginal Australia be trained in relevant cross-cultural disciplines? And might it not be reasonable to expect that those same employees and agents be accountable to their clients and the broader population in accordance with the success or otherwise of their activities in the context of reasonably measured and qualified policy goals and outcomes. In other words, with the benefit of hindsight, as the catalyst of foresight and the reasonable expectation of sound public servicing, it is foreseeable that had Yagga Yagga been supported moderately and sensibly, with responsible degrees of compassion, understanding, professionalism and practicality, it might still be there, the homelands might still flourish and people's lives might be healthier and happier than they are today.

\section{References}

Aboriginals Benefit Account (ABA) 2006. Aboriginals Benefit Account Annual Report 2006-2007. Canberra: Office of Indigenous Policy Coordination.

Akerman, K. 1980. Survey of Sites of Ethnographic Importance in the Area of Mobil Oil Australia Ltd., 1980 Seismic Program in Ep's 219 and 134. Broome, WA: Kimberley Land Council.

Akerman, K. 1981. Survey of Sites of Ethnographic Importance in the Area of Mobil Oil Australia Ltd., 1980 Seismic Program in Ep's 219 and 134. Broome, WA: Kimberley Land Council.

Akerman, K. 1982. Survey of Sites of Ethnographic Importance in the Area of Mobil Oil Australia Ltd., 1980 Seismic Program in Ep's 219 and 134. Broome, WA: Kimberley Land Council.

Altman, J. and Levitus, R. I. 1999. The allocation and management of royalties under the Aboriginal Lands Rights (Northern Territory) Act: Options for reform. CAEPR Discussion Paper 191. Canberra: Centre for Aboriginal Economic Policy Research. 
Altman, J., Gillespie, D. and Palmer, K. 1998. A national review of outstation resource agencies, 1998. Confidential Report to ATSIC. Canberra.

Anon. 1989. Report by the Balgo Aboriginal Task Force, October 1989. Perth: Aboriginal Areas Protection Authority.

Aboriginal and Torres Strait Islander Commission (ATSIC) 1992. Aboriginal and Torres Strait Islander Commission Corporate Plan: 1992-1996, Attachment C. Canberra: Commonwealth of Australia.

Blagg, H. and Valuri, G. 2003. An Overview of Night Patrol Services in Australia. Crime Research Centre. University of Western Australia. Canberra: Commonwealth Attorney-General's Department.

Blanchard, C. A. 1987. Return to Country: The Homelands Movement in Australia. House of Representatives Standing Committee on Aboriginal Affairs. Canberra: Australian Government Publishing Services.

Cane, S. B. 1989. Return to the desert. Report to Department of Aboriginal Affairs and Wirimanu Aboriginal Council.

Cane, S. B. 2006. Countrymen: An ethnography of the Ngurrurpa Native Title claim. A Connection Report to Ngaanyatjarra Council and the Office of Native Title, Department of Premier and Cabinet. Perth: Government of Western Australia.

Cane, S. B. and Novak V. 1980. An archaeological survey of the White Hills prospect area EP134, north western Australia.

Cane, S. B. and Novak, V. 1981. Archaeological Survey of EP 134 West of Stansmore Range. Perth: Department of Aboriginal Sites, Western Australian Museum.

Cane, S. B. and Stanley, O. 1985. Land Use and Resources in Desert Homelands. Darwin: North Australia Research Unit.

Cane, S. B. and Stanley O. 1990. Returning to the desert: Stage two. A Report to ATSIC and Yagga Yagga Community.

Collins, B., Huggins, J. and Hannaford, J. 2003. In the Hands of the Regions-A New ATSIC: Report of the Review of the Aboriginal and Torres Strait Islander Commission. Canberra.

Coombs, H. C., Brandl, M. M. and Snowden, W. E. 1983. A Certain Heritage. CERS Monograph. Canberra: The Australian National University.

Cowan, J. 1994. Wirrimanu: Aboriginal Art from Balgo Hills. London: Gordon \& Breach International. 
Cowan, J. 1999. Balgo, New Directions. Sydney: Craftsman House.

Curtis, J., Hooland, I., Kelly, A., Watling, T., Rogers, B., Babyack, S. and Drinkwater, C. 2005. After ATSIC: Life in the Mainstream. Canberra: Select Committee on the Administration of Indigenous Affairs.

De Ishtar, Z. 2005. Holding Yawulyu: White Culture and Black Women's Law. Melbourne: Spinifex Press.

Department of Indigenous Affairs (DIA) 2005. Overcoming Disadvantage in Western Australia Report. Key Indicators 2005. Perth: Department of Indigenous Affairs.

Ellias, D. 2007. The measure of dreams. In J. Weiner and K. Glaskin (eds), Customary Land in Tenure and Registration in Australia and Papua New Guinea: Anthropological Perspectives. Asian Pacific Monograph 3. Canberra: The Australian National University, pp. 233-46.

Fraser, M. and Simons, M. 2010. Malcolm Fraser: The Political Memoirs. Melbourne: Miegunyah Press.

Guild, F. 1988. Office workers flee as violence hits mission. West Australian, November.

Hawke, S. and Gallagher, M. 1989. Noonkanbah: Whose Land, Whose Law. Fremantle, WA: Fremantle Arts Centre Press.

Hope, N. 2011. Record of investigation into death. Suicide of five young men between 2008 and 2010. Coroner's Court Western Australia 2011 23/11. Perth.

Kapululangu 2007. Aboriginals Have Answers Themselves: Report of the Balgo Women's Law Camp, 24-27 August 2007. Balgo, WA: Kapululangu Aboriginal Women's Association.

Kimberley Land Council (KLC) 1979. Newsletter 1(1).

McCausland, R. 2005. The new mainstreaming of Indigenous affairs. Briefing Paper No. 3. Sydney: Jumbunna Research Unit, University of Technology.

McCoy, B. 2008. Holding Men: Kanyirninpa and the Health of Young Aboriginal Men. Canberra: Aboriginal Studies Press.

Manning, I. 1997. Native Title, Mining and Mineral Exploration: The Impact of Native Title and the Right to Negotiate on Mineral and Mineral Exploration in Australia. Canberra: Aboriginal and Torres Strait Islander Commission. 
Manning, I. 2002. The Aboriginal Benefits Account: Its management, investments, performance-A history. Paper prepared for the Northern Land Council, Darwin.

Myers, F. R. 1976. To have and to hold: A study of persistence and change in Pintupi social life. PhD thesis. Bryn Maw College, Pennsylvania.

Myers, F. R. 1986. Pintupi Country, Pintupi Self: Sentiment, Place, and Politics among Western Desert Aborigines. Washington, DC: Smithsonian Institution Press.

Nathan, P. and Japanangka, D. 1983. Settle Down Country. Melbourne: Kibble Books.

Nicholls, C. and Williams, S. 2006. Luurnpa, the Magical Kingfisher: A Dreaming Narrative Belonging to Bai Bai Napangarti. Adelaide: Working Title Press.

O'Donoghue, L. 1992. Message from the Chairperson: Taking control. In ATSIC Corporate Plan 1992-1996. Canberra: Aboriginal and Torres Strait Islander Commission.

Paganoni, L. 2003. Community turns into ghost town. West Australian, 1 December.

Palmer, K. 1980. Aboriginal relations to the land west of the Stansmore Range: An anthropological study of Aboriginal land tenure and religious beliefs in an area west of the Stansmore Range in the Great Sandy Desert, Western Australia. Report prepared for Mobil Oil.

Penny, D., Davis, K. and Hunter, J. 1977. Papunya: History and future projects. Report to DAA. Alice Springs, NT: Department of Aboriginal Affairs.

Poirier, S. 2005. A World of Relationships: Itineraries, Dreams, and Events in the Australian Western Desert. Toronto: University of Toronto Press.

Sanders, W. 2004. ATSIC's Achievements and Strengths: Implications for Institutional Reform. Canberra: Centre for Aboriginal Economic Policy Research.

Scambary, B. 2013. My country, mine country: Indigenous people, mining and development contestation in remote Australia. CAEPR Research Monograph 33. Canberra: Centre for Aboriginal Economic Policy Research.

Snowdon, W. E. 1990. Our Future Ourselves: Aboriginal and Torres Strait Islander Community Control Management and Resources. House of Representatives Standing Committee on Aboriginal Affairs. Canberra: Australian Government Printer. 
Stead, G. 1982. Kintore review. Unpublished report. Department of Aboriginal Affairs, Alice Springs, NT.

Sutton, P. 2009. The Politics of Suffering: Indigenous Australia and the End of the Liberal Consensus. Melbourne: Melbourne University Press.

Tjama, F., Pay Payi, N., Martingale, M., Kuninyi, R., Nanyuma, R. and Skeen, M. 1997. Yarrtji: Six Women's Stories from the Great Sandy Desert. Canberra: Aboriginal Studies Press.

Vanstone, A. 2005a. Address to the National Press Club, Canberra, 23 February 2005.

Vanstone, A. 2005b. Beyond conspicuous compassion: Indigenous Australians deserve more than good intentions. Lecture, 7 December 2005.

Vanstone, A. 2005c. Indigenous communities becoming cultural museums. Transcript, $A B C$ Radio, 9 December.

Watson, C. 1999. Touching the land: Towards an aesthetic of Balgo contemporary painting. In H. Morphy and M. Smith Boles (eds), Art from the Land: Dialogues with the Kulge-Ruhe Collection of Australian Aboriginal Art. Virginia: University of Virginia, pp. 163-218.

Watson, C. 2003. Piercing the Ground: Balgo Women's Image Making and Relationships to Country. Fremantle, WA: Fremantle Arts Centre Press. 
This text is taken from Experiments in self-determination: Histories of the outstation movement in Australia, edited by Nicolas Peterson and Fred Myers, published 2016 by ANU Press, The Australian National University, Canberra, Australia. 